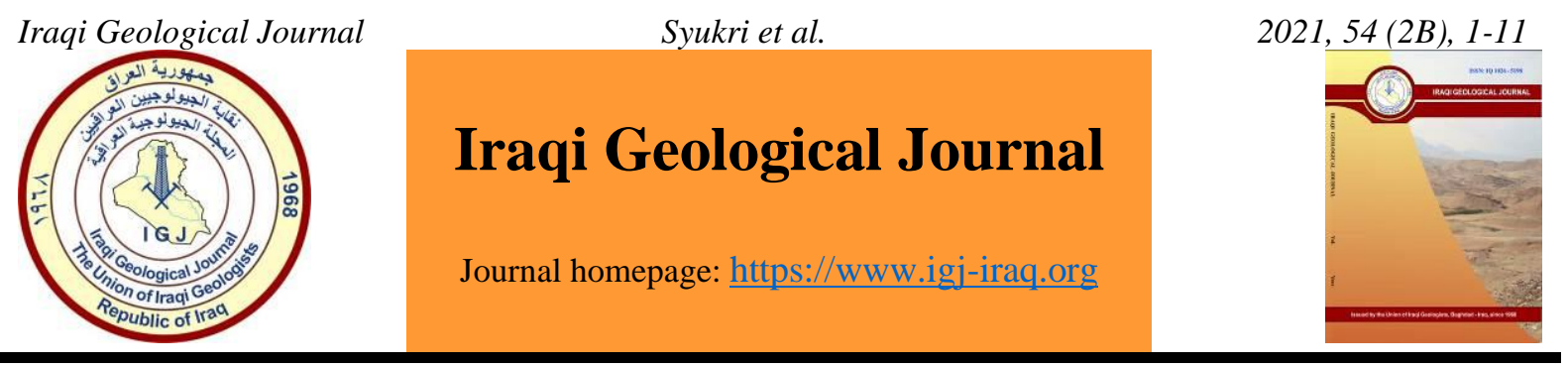

\title{
Spatial and Temporal Analysis of b-value Imaging Characteristics Using High Precision Earthquake Spot in the Sumatran Subduction Zone
}

\author{
Muhammad Syukri ${ }^{1,2}$, Dian Darisma ${ }^{2, *}$, Farah Annisa Cahyani ${ }^{2}$ and Cahyani ${ }^{3}$ \\ 1 Department of Physics, Faculty of Mathematics and Science, Universits Syiah Kuala, Indonesia \\ 2 Geophysical Engineering Department, Faculty of Engineering, Universitas Syiah Kuala, Indonesia \\ 3 Meteorology, Climatology, and Geophysical Agency, Mata Ie Station, Banda Aceh, Indonesia \\ * Correspondence: diandarisma@unsyiah.ac.id
}

Received: 3 April 2021; Accepted: 26 May 2021; Published: 31 August 2021

\begin{abstract}
Sumatra is one of the Indonesian regions categorized as active tectonics. The majority of past earthquakes in Sumatra and its surrounding areas have originated from the accumulated stress in the subduction zone, namely the submergence of the Indo-Australian plate against the Eurasian plate. This research was conducted to identify the level of accumulated stress and earthquake-prone areas in the subduction zone of Sumatra Island based on the spatial variation of the b-value, using the least square method. The data used in this study are earthquake parameter data from the International Seismological Center the United States Geological Survey and Meteorological, Climatological, and Geophysical Agency catalogs from 2005-2019 with a magnitude $\geq 1$ and a depth of $0-200 \mathrm{~km}$ located $90^{\circ}$ to $106^{\circ} \mathrm{E}$ and $-6^{\circ}$ to $5.8^{\circ} \mathrm{S}$. The results showed that the spatial variation of the bvalue in the subduction zone of Sumatra Island in 2005-2009 ranged from 0.31-0.77, the b-value for 2010-2014 ranged from 0.18-1.29. In 2015-2019, the spatial variation of b-values ranged from 0.28-1.2. Earthquake-prone areas are located around Breuh Island, Banyak Islands, and Sipura and Pagai Islands, as evidenced by a low bvalue, correlating with a high level of unreleased accumulated stress from the past 15 years, leading to an immense earthquake potential in the next period within the area. This analysis shows very significantly found that high b-value matches with earthquake spots. Detailed spatial and temporal b-value characteristics and its interpretation can advance our comprehension of earthquake occurrence and ideally lead to improved forecasting agility.
\end{abstract}

Keywords: Sumatra; Subduction; b-value; Earthquake; Seismicity

\section{Introduction}

Indonesia is a confluence of three active tectonic plates, namely the Indo-Australian Plate, the Eurasian Plate, and the Pacific Plate. The interaction of the three tectonic plates makes Indonesia a country with a high level of earthquake activity. Sumatra Island has shown histories of tectonic activity with over 20 devastating earthquakes over the past 100 years (Natawidjaja et al., 2007). Sumatra Island is tectonically influenced by three tectonic zones: the subduction zone, the Mentawai Fault, and the large fault zone of Sumatra. Subduction zones are the most dominant source of earthquakes (Bock et al., 2003; Mccaffrey, 2009; Moeremans and Singh, 2015).

DOI: $10.46717 /$ igj.54.2B.1Ms-2021-08-21 
Four major earthquakes with a magnitude of over 8.0 have occurred since 1976, including the 2004 Sumatra Mw 9.1 earthquake (Pollitz et al., 2006), the 2005 Nias Mw 8.6 earthquake (Meltzner et al., 2012), and the 2012 East Indian Ocean Mw 8.6 and Mw 8.2 earthquake (Pollitz et al., 2012). Other large earthquakes above Mw 7.5 include the 2009 Padang Mw 7.6 earthquake, 2010 Banyak Island Mw 7.8 earthquake, and $2010 \mathrm{Mw} 7.8$ Mentawai earthquake, which were accompanied by a tsunami (Bilek et al., 2011; McCloskey et al., 2010; Tsang et al., 2015). These events show how crucial it is to have studies on earthquakes originating from subduction zone activities such as observing earthquake activity based on the level of energy accumulation and release (Awadh, 2021). A method that can be used to examine earthquake activity is by analyzing b-value variations (Bora et al., 2018; Hatzidimitriou et al., 1985; Molchan and Dmitrieva, 1990). The variation of the b-value is a seismotectonic parameter of an area usually close to 1 and shows the relative number of small and large vibrations (Aki, 1965; Al-Ridah and Mohammed, 2017; Gutenberg and Richter, 1944).

Thermal gradient and rock heterogeneity are factors that can influence the b-value (Mogi, 1963; Westerhaus et al., 2002). A high b-value in an area will indicate a high rock brittleness (Nuannin et al., 2005). The level of rock brittleness indicates the resistance of the rock to stress received by endogenous forces in the earth's layer (Shakir and Barno, 2020). On the other hand, small shear stress indicates a small $b$-value (Urbancic et al., 1992; Wiemer and McNutt, 1997). Changes in $b$-value before a big earthquake can occur (Scholz, 1968). Variation of b-values throughout months and years has been known to occur before significant earthquakes in various parts of the world. Imoto (1991) explained that the decrease in b-value was seen several years before the earthquake with $\mathrm{Mw}>6.0$. Sahu and Saikia (1994) observed that the $b$-value decreased before an earthquake happened with $\mathrm{Mw} 7.3$ that occurred on the India-Myanmar border in 1988. In addition, the $b$-value also decreased before the big earthquake on the Pacific Coast of Tokachi in 2003 (Mw 8.0) and 2008 (Mw 7.1) (Xie et al., 2019).

Sumatra, as an area with high seismic levels, has been carried out seismic studies by several researchers who studied the distribution of coseismic slips and the intraplate response of the 2004 Sumatra earthquake and 2005 Nias earthquake (Andrade and Rajendran, 2011; Banerjee et al., 2007). Nuannin et al. (2005) studied the accumulated stress and b-values after the 2004 Sumatra earthquake for five years. The results showed that the $b$-value dropped significantly after the big earthquake in 2002 . In another research, Nuannin and Kulhánek (2012) explained that the major earthquakes in the Andaman-Sumatra area occurred when the $b$-value decreased by around 0.3 - 1.0. Pailoplee et al. (2013) conducted a study in the northern part of the Sumatra-Andaman subduction zone based on the $b$-value to identify zones where earthquakes were likely to occur. Meanwhile, this research was conducted to determine the spatial variation of $b$-values in the subduction zone of Sumatra Island to identify subsurface stress levels based on earthquake data between 2005-2019. It is hoped that the results of this research can provide useful information for the development of disaster research.

\section{Tectonic Setting}

Indonesia is located at the southeastern tip of the Eurasian lithosphere plate. This region is bounded by the Indo-Australian plate moving north and the Pacific moving west (Philippines). The Sumatran subduction zone resulted from the collision of the Indo-Australian Plate and the Eurasian plate known as the megathrust (Fig. 1)Error! Reference source not found.. The Sumatra subduction system is characterized by producing a series of the non-volcanic island (Simeulue Island, Nias, Banyak, Batu, Siberut to Enggano Island); these islands have no volcanic activity. The Indo-Australian plate descends under the Eurasian plate at varying speeds along the trench of about $43 \mathrm{~mm} / \mathrm{year}$ on Nicobar Island (Gahalaut et al., 2006), $52 \mathrm{~mm} /$ year in North Sumatra, and $63 \mathrm{~mm} /$ year in South Sumatra (Barber et al., 2005; Prawirodirdjo and Bock, 2004). On Sumatra Island, there is a strike-slip component known as the Great Sumatran Fault (GSF). GSF is a dextral trending strike-slip fault consisting of 20 main segments 
along the Sumatra Island (Collings et al., 2012; Sieh and Natawidjaja, 2000). The GSF line is characterized by the landscapes along the route, which are hills and lakes, which are formed due to shifts in these faults. This $\pm 1900 \mathrm{Km}$ fault line crosses the ridge of Sumatra Island along with the Barisan Hill. In addition, there is the Mentawai Segment, which is a seismic gap area that has yet to experience relaxation (Chlieh et al., 2008; Konca et al., 2008). The Mentawai fault is a horizontal fault caused by a sloping process around Sumatra Island. The Mentawai fault is in the sea extending around the Mentawai islands from South to North continuously to the North Nias areas.

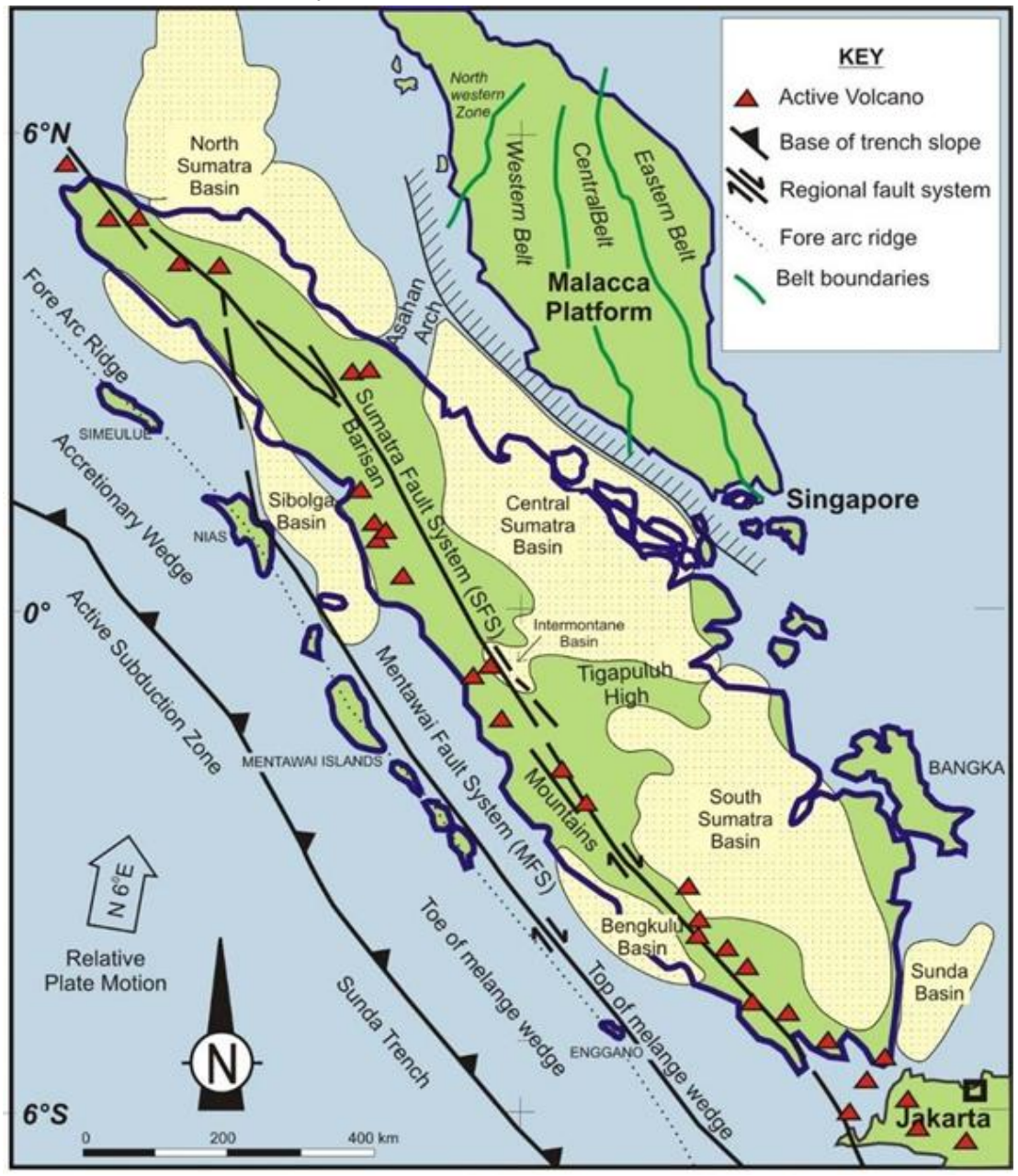

Fig. 1. Plate tectonics of the Sumatra Island (Darman and Sidi, 2000)

Most major earthquakes in the Sumatra and the surrounding area originated from the Sumatran subduction zone. Past earthquakes show that over 20 destructive earthquakes have occurred in this area in the past 100 years. Earthquakes in the Sumatra can occur every five years, while the Sumatran subduction zone shows the potential for an over Mw 8 earthquake can occur two or three times in 100 years (Natawidjaja et al., 2007). Earthquakes in the GSF are more common and can be felt by the people as it is closer to them. The extensive history of destructive earthquakes along the GSF places the need for earthquake and tsunami disaster mitigation from subduction zones (Bock et al., 2003).

\section{Materials and Methods}

This study uses earthquake data from 2005-2019 with a magnitude body (Mb) $>1$, and the majority of data is at a depth of $20-40 \mathrm{~km}$. The location of the research area is at $90^{\circ} \mathrm{E}$ to $106^{\circ} \mathrm{E}$ and $-6^{\circ} \mathrm{S}$ to $5.8^{\circ} \mathrm{S}$. Earthquake data uses catalog data from ISC (International Seismological Center), USGS (United States Geological Survey), and BMKG (Meteorology, Climatology, and Geophysics Agency). This research 
is divided into three groups, starting from 2005-2009, 2010-2014, and 2015-2019. This was done to identify the difference in the subsurface stress conditions in the subduction zone of the Sumatra Island with various earthquake activities for five years. The earthquake data is then processed to obtain the rock brittleness level (b-value) which is divided into several regions (Fig. 2). This value is calculated using the Gutenberg and Richter formula (Gutenberg and Richter, 1944):

$$
\log N(M)=a-b M
$$

where $\mathrm{N}=$ number of earthquakes, and $\mathrm{M}=$ magnitude of earthquakes. The values of $\mathrm{a}$ and $\mathrm{b}$ are calculated using the following least-square method:

$$
\begin{aligned}
& b=\frac{n \sum\left(X_{i} Y i\right)-\left(\sum X_{I}\right)\left(\sum Y_{I}\right)}{n \sum X_{i}^{2}-\left(X_{i}\right)^{2}} \\
& a=\frac{\sum Y_{i}-b \sum X_{i}}{n}
\end{aligned}
$$

where $\mathrm{Xi}=$ midpoint of magnitude class, $\mathrm{Yi}=$ logarithm of earthquake frequency for a given magnitude class, $\mathrm{n}=$ number of magnitude classes. This method analyzes how close the relationship is between two or more variables with a small error rate (Guttorp, 1987). The least-squares method is used for data that has a linear correlation (Al-Heety, 2016).

An area with a high a-value indicates that the area has high seismic activity while an area with a low a-value indicates that the area has low seismic activity. The low seismic activity in the active earthquake zone is due to the accumulation of energy in that area. This can be seen from the b-value tectonic parameter based on the frequency of earthquakes that occur in the area. The b-value is used to determine changes in physical phenomena that are observed before an earthquake, namely the accumulated stresses which will then be released during an earthquake (Scholz, 1968; Wyss, 1973). The determination of $b$-value is based on the threshold of magnitude known as the magnitude of completeness Mc. This value is an important factor in data quality control. In this study, Mc was estimated using the Maximum Curvature (MAXC) technique. By using 15,508 earthquake data from 2005-2019, the Mc value is 4.4.

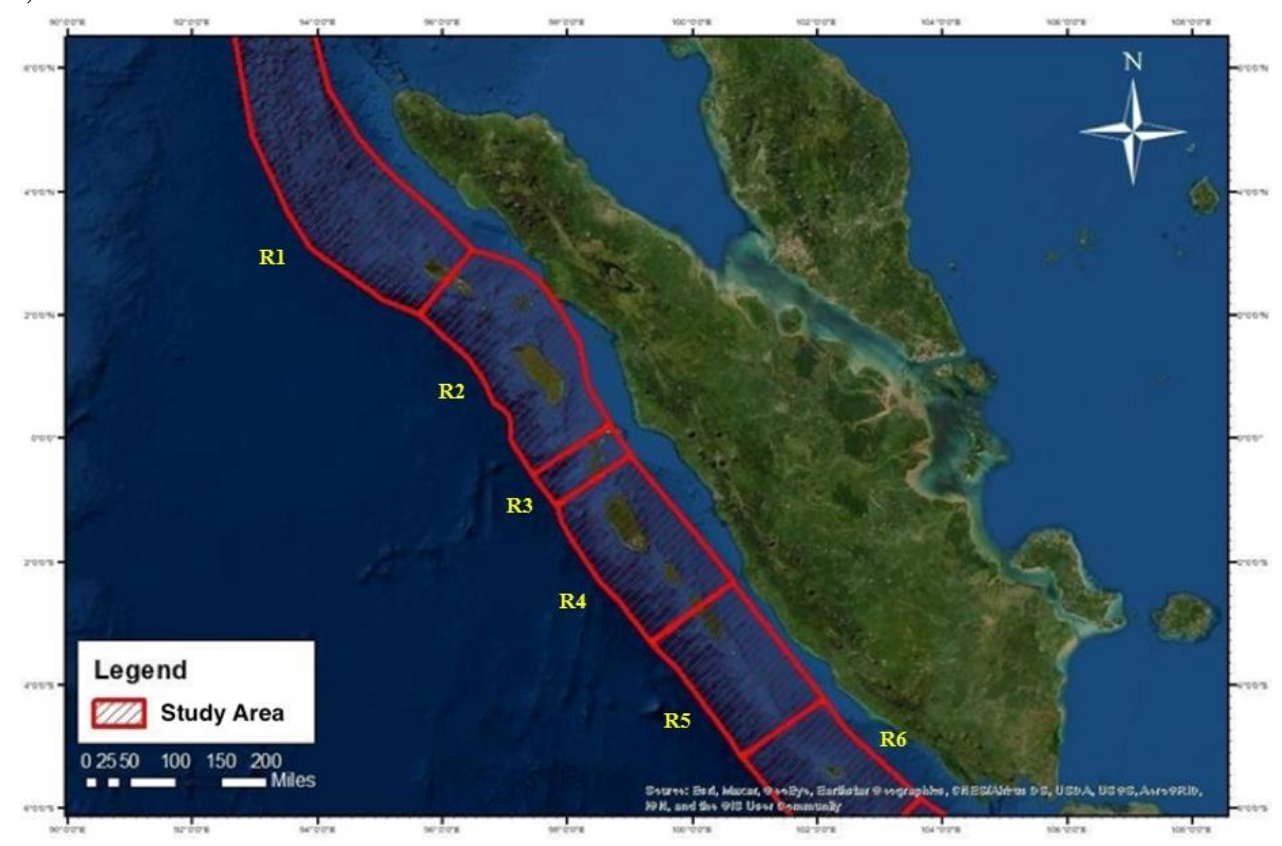

Fig. 2. Location map in the Sumatran Subduction zone 


\section{Results}

This research was conducted in the subduction zone of the Sumatra Island using secondary data for the last 15 years of the 2005-2019 period obtained through the catalogs of USGS, ISC, and BMKG. There are 15,508 combined data with a magnitude range of 1-9 Richter. The distribution of earthquakes that occurred during this period can be seen in Fig. 3Fig. 3. The map shows that the majority of earthquakes in this area occur along the Sumatra subduction zone. This is due to the movement of the Indo-Australian plate towards the Eurasian Plate at a speed of 4-7 cm/year from north to south (Barber et al., 2005).

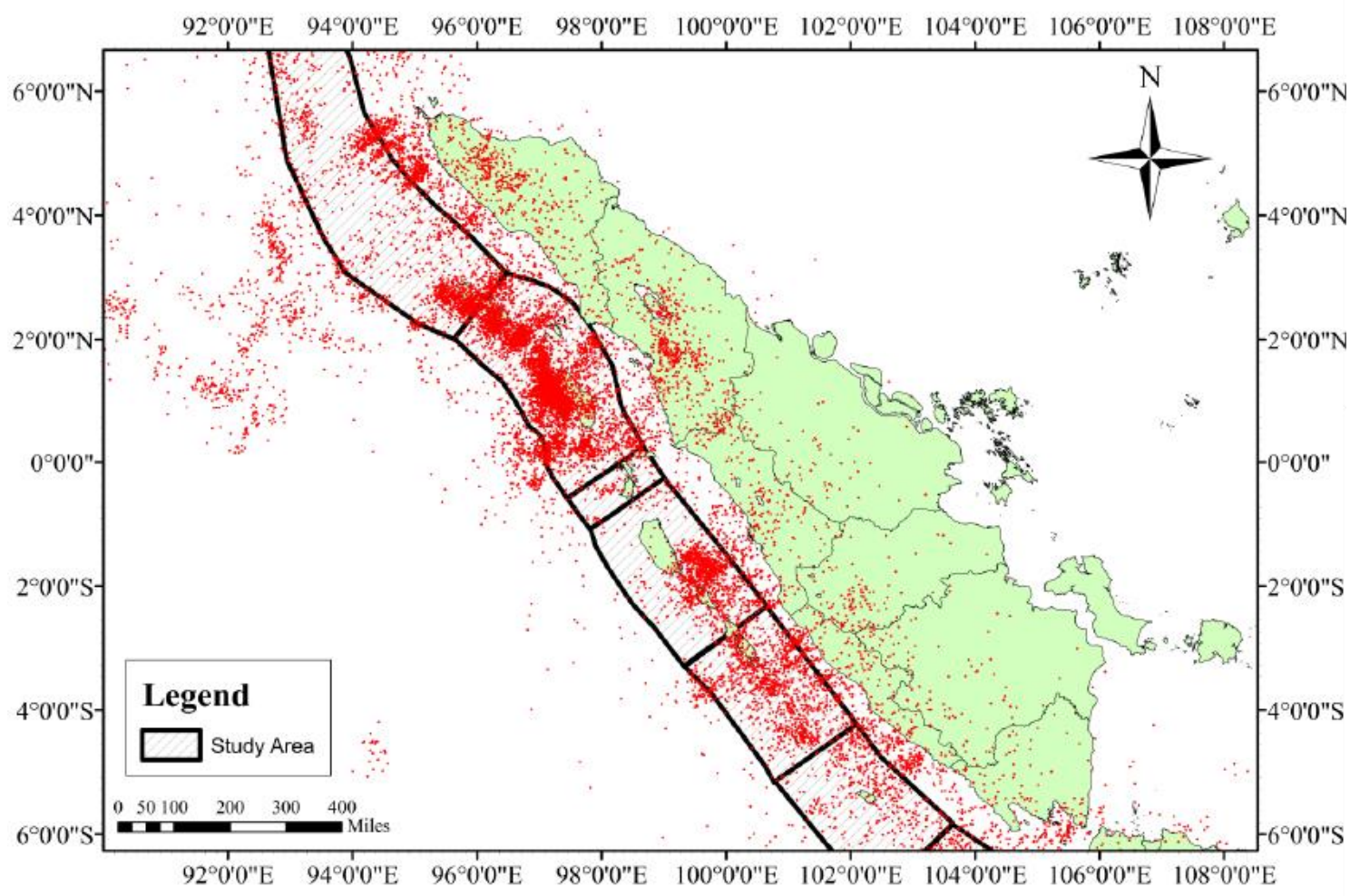

Fig. 3. Distribution of earthquakes in the subduction zones for 2005-2019

The earthquake data is then plotted to identify the frequency of earthquakes that occur each year (Fig. 4Fig. 4). The highest earthquake frequency occurred in 2005 with 6.462 earthquakes, while the lowest was in 2017 with 468 earthquakes. After the 2004 earthquake, many aftershocks occurred in 2005. After the stress relief that occurred in 2004, the subduction zone still founds its relaxation zone, which causes many aftershocks that occurred in 2005 . Then the earthquake period that occurred starting in 2009 began to stabilize. The graph shows that over the last 15 years, the frequency of earthquakes has decreased; this means that the accumulated energy in the subduction zone has not been released. In addition, the earthquake data is also plotted to identify the magnitude of earthquakes that often occur in this area. Fig. 5 shows that earthquakes with a magnitude of 4-5 have occurred more frequently, reaching 10.523 times in the last 15 years. Generally, the relationship between earthquake magnitude and frequency is inversely proportional; this shows that earthquakes with small magnitudes occur more frequently than large earthquakes (Gutenberg and Richter, 1944).

The results of the b-value using the least square method can be seen in Fig. 6Fig. 6 for the 20052009 data period, Fig. 7Fig. 7 for the 2010-2014 data period, and Fig. 8Fig. 8 for the 2015-2019 data period. Fig. 6Fig. 6 shows that the low b-value ranges from $0.31-0.41$, while the high b-value ranges from 0.63-0.77. The zone that has a higher b-value is around the Aceh Sea (R1) and Enggano Island 
(R6), and areas that have a lower b-value is around Breueh Island (northern part of R1) and from Banyak Islands to Pagai Island (R2-R5). In the second period 2010-2014 (Fig. 7Fig. 7), low b-values ranged from $0.18-0.44$, and high $b$-values ranged from $0.7-1.29$. This period has the lowest $b$-value of 0.18 and the highest at 1.29. The zone with the highest b-value is around the Aceh Sea (R1), but there is a slight difference from the previous period. Zones with the lowest $b$-value are from Banyak Islands to Pagai Islands (R2-R5), and Breueh Island (northern part of R1). Furthermore, in the third period 2015-2019, Fig. 8 shows a low $b$-value ranging from $0.28-0.38$, and the high $b$-value ranges from 0.60-1.2. In this period, the highest b-value is also around the Aceh Sea (R1), and the lowest value is around Breueh Island (northern part of R1), and Banyak Islands to Pagai island (R2-R5).

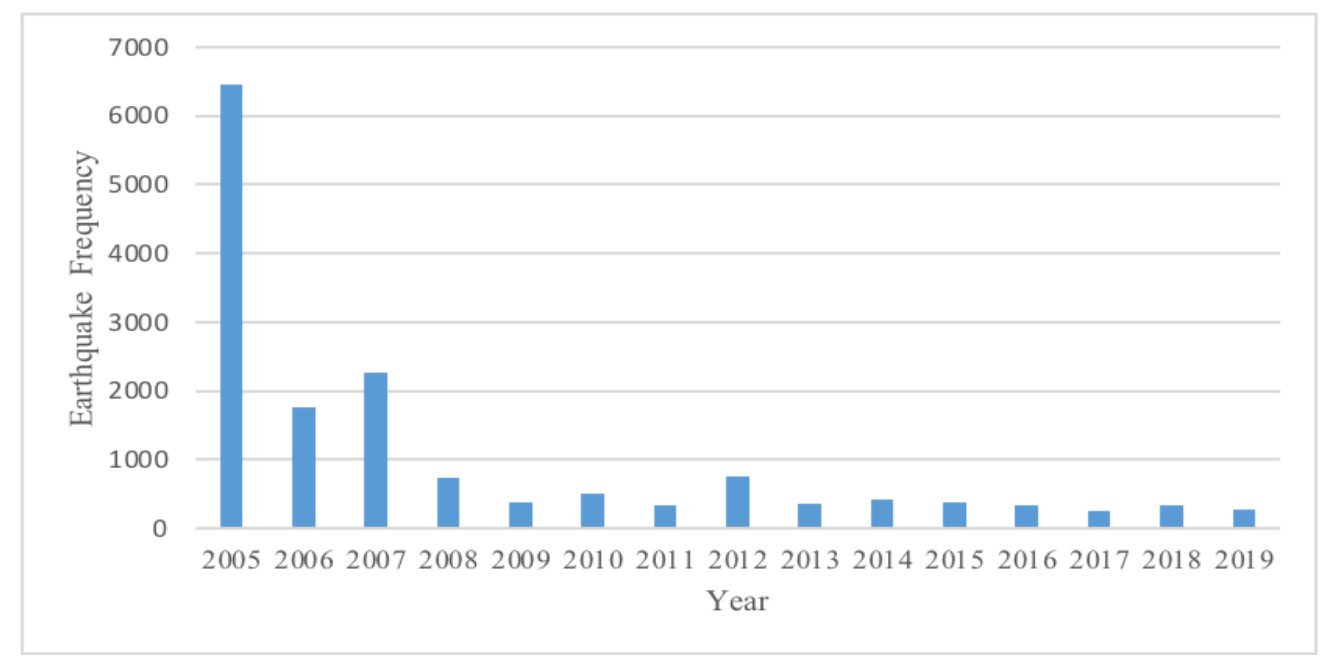

Fig. 4. Earthquake frequency in Sumatran subduction zone 2005-2019

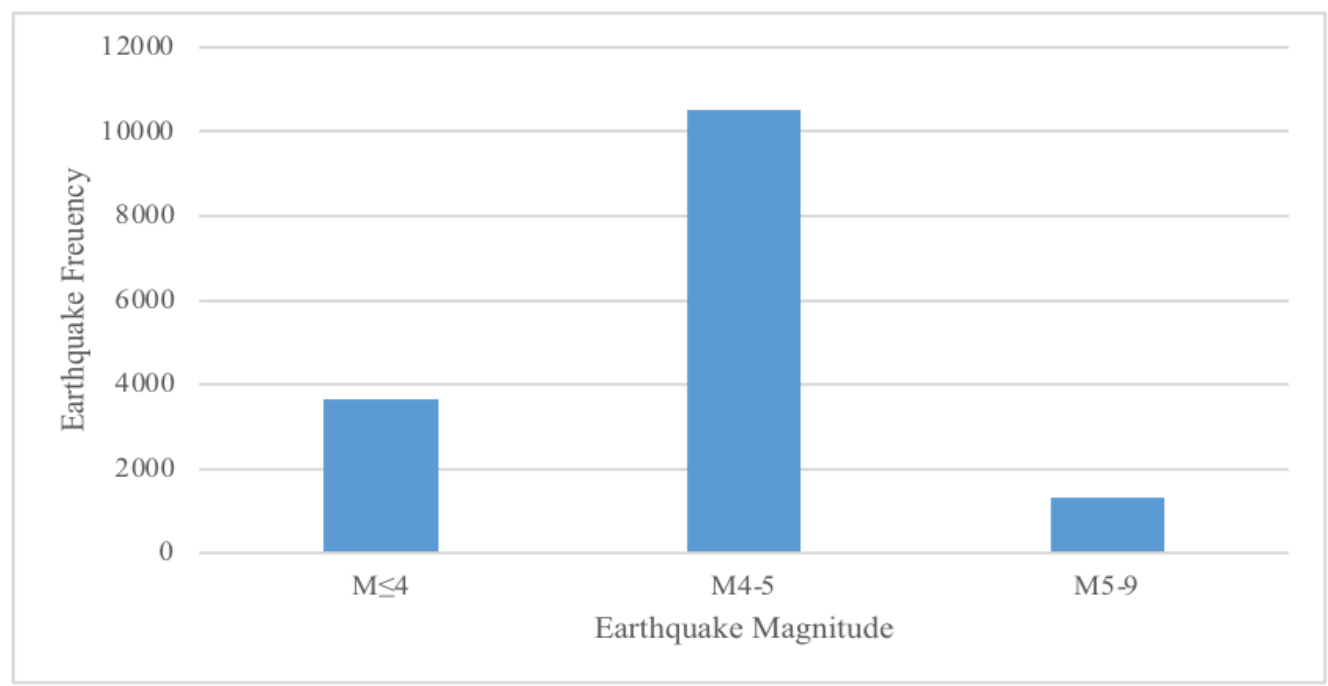

Fig. 5. Earthquake based on the magnitude in Sumatran subduction zone 2005-2019

\section{Discussion}

In general, a decrease in the b-value can be interpreted as an increase in stress before an earthquake. These changes can be seen in the series of years before and after the earthquake occurred. Nuannin et al. (2005) conducted a b-value study to observe changes that occurred after the big earthquake in 2004 on the coast of NW Sumatra using data from 2000 to 2004. The results show that the significant decrease in b-value before the two major earthquakes in 2002 and 2004 was around 0.2-0.4. A decrease in b- 
value was also obtained before the occurrence of several earthquakes around the Sumatra-Andaman Subduction Zone (Pailoplee et al., 2013).

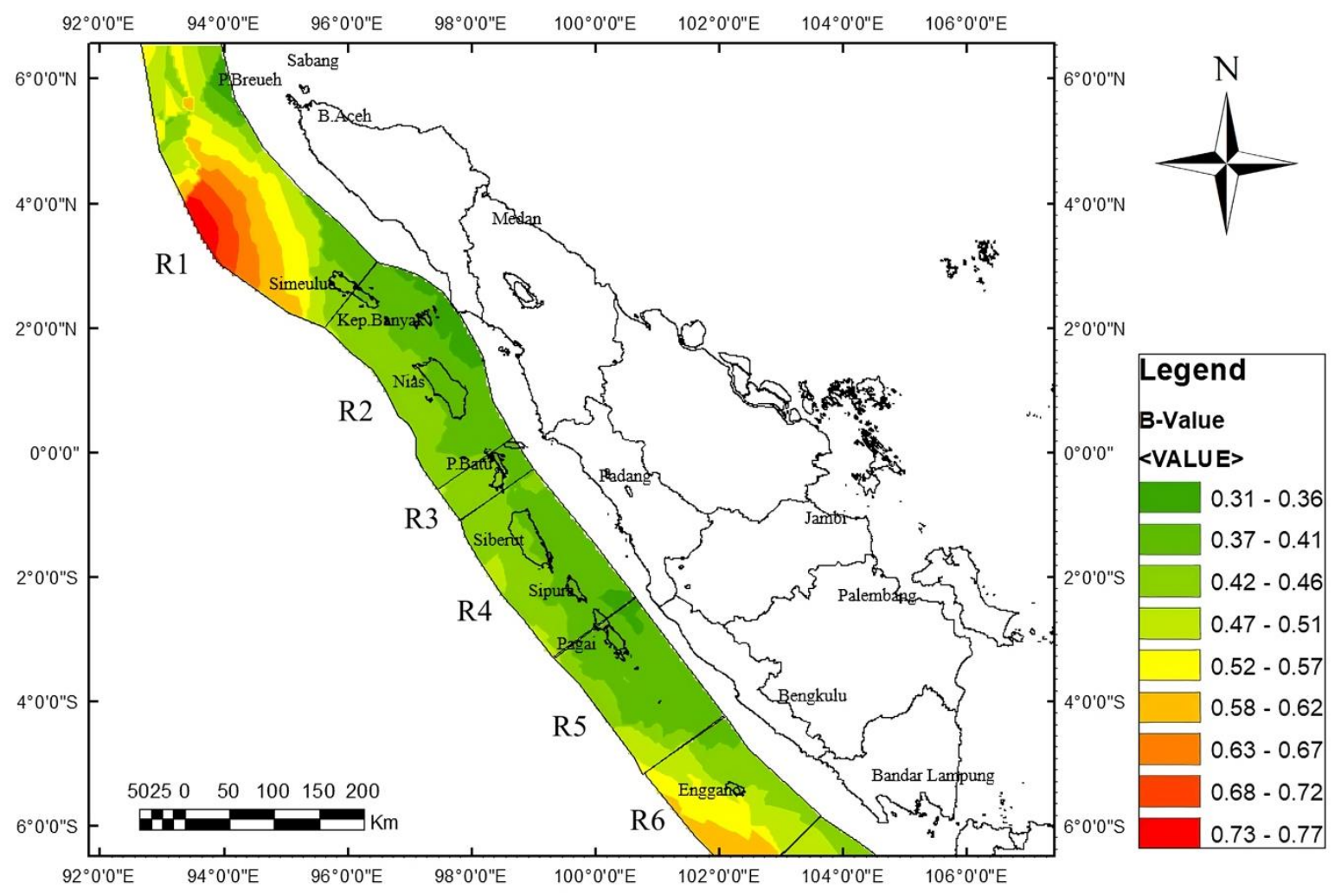

Fig. 6. Spatial variation of b-value in the subduction zone of Sumatra Island in 2005-2009

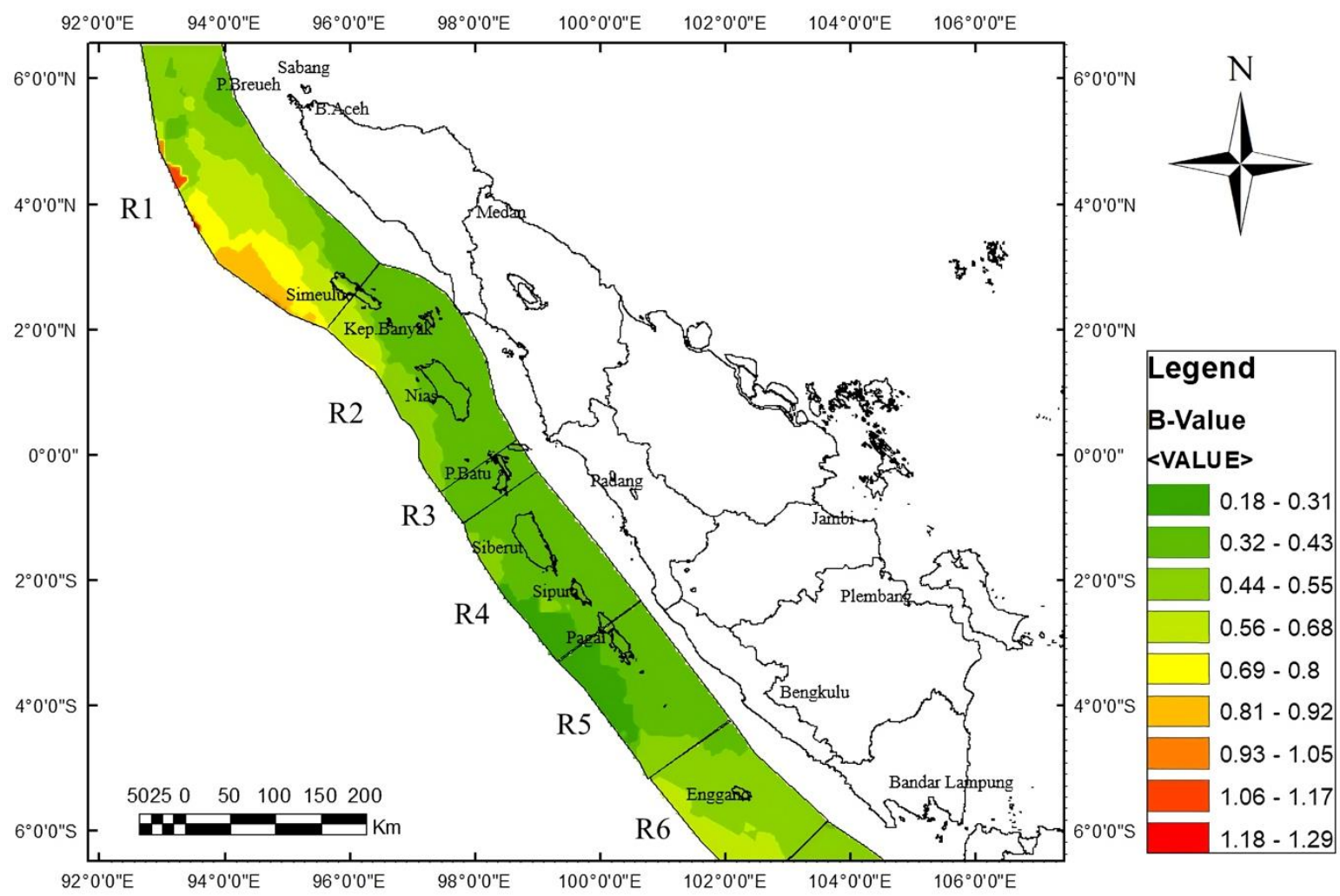

Fig. 7. Spatial variation of b-value in the subduction zone of Sumatra Island in 2010-2014 


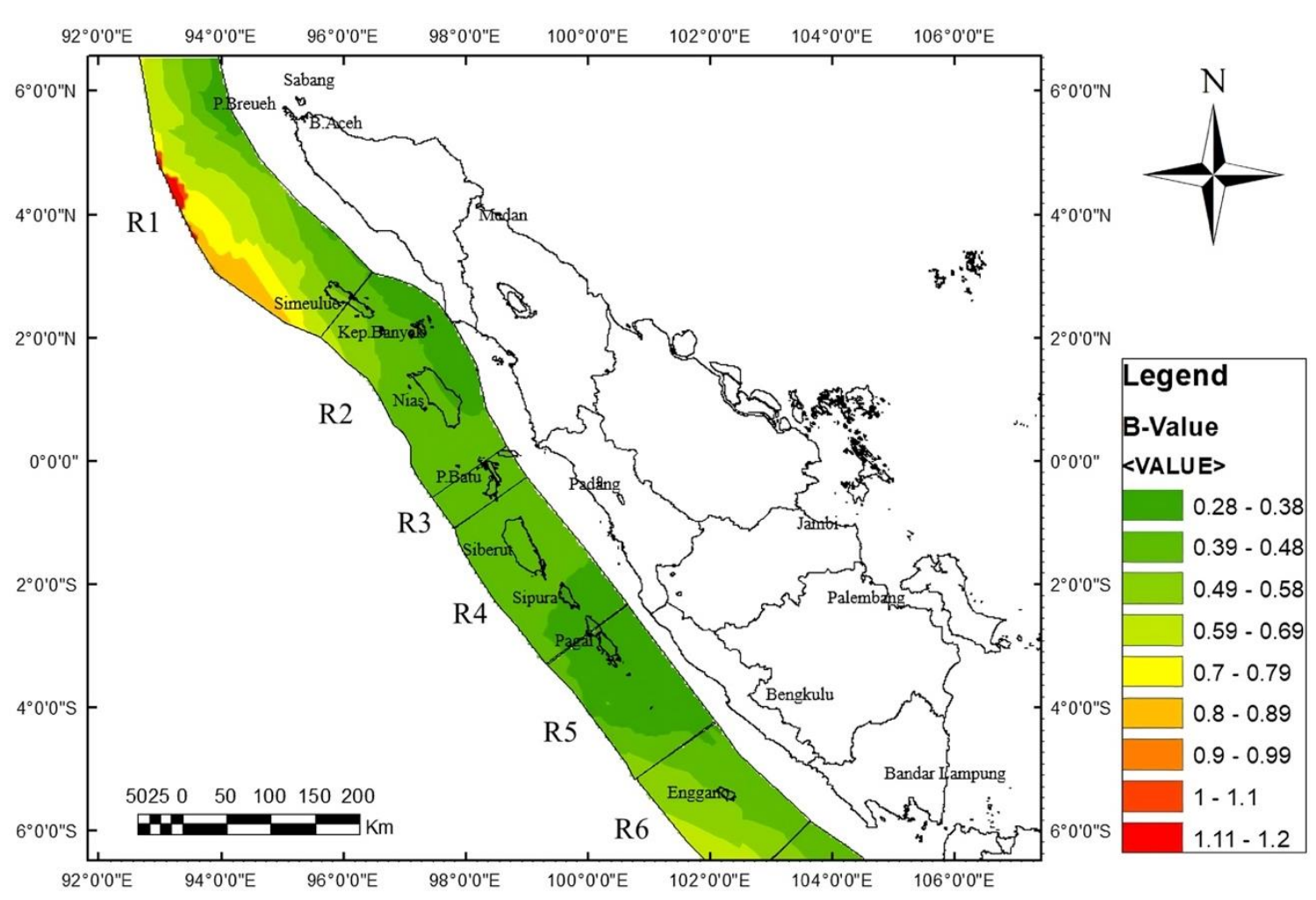

Fig. 8. Spatial variation of b-value in the subduction zone of Sumatra Island in 2015-2019

In this study, spatial variation of b-values is evaluated only around Sumatran Subduction Zone using 15,508 earthquake data from 2004 to 2019 that focuses on how b-value changes after the 2004 Sumatra Mw 9.1 earthquake and other $\mathrm{Mw}>7.0$ earthquakes. The decrease in b-value for earthquakes in the $\mathrm{R} 1$ zone around Aceh Sea $(\mathrm{Mw}=7.2)$ in May 2010 and the Banyak Islands $(\mathrm{Mw}=7.8)$ in March 2010 was around $0.37-0.41$ (Fig. 6) to $0.32-0.43$ (Fig. 7). The earthquake that occurred around the Pagai Islands $\mathrm{R} 5(\mathrm{Mw}=7.8)$ in 2010 was also marked by a decrease in the b-value from 0.37-0.41 (Fig. 6) to 0.32-0.43 (Fig. 7).

Another study conducted by Nuannin and Kulhanek (2012) shows that large earthquakes that occurred in the Andaman-Sumatra area caused the b-value to decrease by around 0.3 to 1.0 using data from 1995 to 2004. These earthquakes occurred at b-values less than 1 with a value range between 0.5 and 1 . These $b$-value observations can be used as earthquake precursors in the medium-term (monthsyears) period. On the other hand, large earthquakes do not occur in areas with high b-values so that they can be used as earthquake precursors for aftershock sequences for a short period (days-months). Areas with a lower b-value are areas with the potential to experience major earthquakes, from unreleased accumulated stresses. Areas with a higher b-value indicate a high level of earthquake activity, be it large or small earthquakes. Nuannin and Kulhanek (2012) also explain that the b-value has increased after two large earthquakes $\mathrm{Mw}=9$ and $\mathrm{Mw}=8.7$ in the vicinity of epicentral areas. In the results of this study, the b-value with a higher value occurred around the epicenter of the 2004 Sumatra earthquake which also became the highest $b$-value around 0.77 (Fig. 6). Then the area with a higher b-value got smaller in the earthquake period 2010-2014 (Fig. 7) and 2015-2019 (Fig. 8) with the earthquake intensity in this area decreasing as seen in Fig. 4. Other major earthquakes $(\mathrm{Mw}>7)$ that occurred in the Sumatran Subduction Zone were the Nias earthquake R2 $(\mathrm{Mw}=8.6)$ in March 2005, the Simeulue earthquake R1 $(\mathrm{Mw}=7.4)$ in February 2008, the West Sumatra earthquake $\mathrm{R} 4(\mathrm{Mw}=7.6)$ in September 2009, the Mentawai earthquakes R4 in September $2007(\mathrm{Mw}=7.9)$ and February $2008(\mathrm{Mw}=7.2)$ (Affan et al., 2016). If we look at the distribution of the b-value in 2005-2009, these large earthquakes occurred in the 
low b-value range of 0.31-0.41. The increase in b-value in some of the earthquake epicenters (Fig. 7) only occurred in the Simeulu and Nias earthquakes with an increase of around 0.07 to 0.14 , while other earthquakes did not change the b-value significantly. The distribution of b-values in the epicenter areas of the earthquake for the three periods 2005-2009, 2010-2014, and 2015-2019 show that the b-value in these areas is still relatively low with a b-value range of $0.18-0.38$. The results of research conducted by Gui et al. (2019) also showed the low b-value around Breuh Island (R1), Nias (R2), and Banyak Islands using data from 2005 to 2015 . Furthermore, when referring to the low b-value hypothesis precursory by Nuannin et al. (2005), these areas are likely to experience earthquakes in the future.

\section{Conclusions}

This study uses earthquake data around the subduction zone of the Sumatra and its surroundings in 2005-2019 with a magnitude of $\mathrm{Mb}>1$ and at a majority depth of 20-40 km. Earthquake data downloaded from the ISC, USGS, and BMKG catalog was used to calculate the b-value. The spatial distribution of the $b$-value is then used to determine the zone with a high level of stress accumulation, which is characterized by a low $b$-value. The spatial variation of the $b$-value in the subduction zone of the Sumatra in 2005-2009 ranged from 0.31-0.77. In 2010-2014, the b-value ranged from 0.18-1.29, and the b-value variation in 2015-2019 ranged from 0.28-1.2. Earthquake-prone areas in the subduction zone of the Sumatra Island are located around Breueh Island, Banyak Islands, and around Sipura and Pagai Islands. This can be proven by the low b-value, which correlates with high unreleased stress levels in the last 15 years. The low b-value accumulates the energy received so that the energy will be released in the form of a big earthquake.

\section{Acknowledgements}

The authors would like to thank the Meteorology, Climatology, and Geophysical Agency, Station of Mata Ie, Banda Aceh, Indonesia for helping us collecting and providing the data, staff of Geophysical Engineering Department, Faculty of Engineering, Universitas Syiah Kuala for supporting the research and laboratory facilities. Special thanks are extended to the Ministry of Education and Culture, Indonesia for financial support in the scheme of Decentralized Research Competitive Grants Program 2021 PDUPT. We are so grateful for all the support received. The authors are very grateful to the Editor in Chief Prof. Dr. Salih M. Awadh, the Secretary of Journal Mr. Samir R. Hijab. and the Technical Editors for their great efforts and valuable comments.

\section{References}

Affan, M., Syukri, M., Wahyuna, L., and Sofyan, H., 2016. Spatial statistic analysis of earthquakes in Aceh Province Year 1921-2014: Cluster seismicity. Aceh International Journal of Science and Technology, 5, $54-62$.

Aki, K., 1965. Maximum likelihood estimates of $\mathrm{b}$ in the formula $\log \mathrm{N}=\mathrm{a}-\mathrm{bM}$ and its confidence limits. Bulletin. Earthquakes Recourses, University of Tokyo. 43, 237-239.

Al-Heety, E.A.M.S., 2016. Spatial analysis of earthquakes in Iraq using statistical and data mining techniques. Iraqi Geological Journal, 39, 1-15.

Al-Ridah, N.A., Mohammed, H.J., 2017. Seismotectonic study of middle and southern Iraq. Iraqi Geological Journal, 50, 24-35.

Andrade, V., and Rajendran, K., 2011. Intraplate response to the great 2004 Sumatra-Andaman Earthquake: A study from the Andaman Segment. Bulletin of the Seismological Society of America, 101, 506-514.

Awadh, S.M., 2021. Solar system planetary alignment triggers tides and earthquakes. Journal of Coastal Conservation, 25(2), 1-12. 
Banerjee, P., Pollitz, F., Nagarajan, B., and Burgmann, R., 2007. Coseismic slip distributions of the 26 December 2004 Sumatra-Andaman and 28 March 2005 Nias earthquakes from GPS static offsets. Bulletin of the Seismological Society of America, 97.

Barber, A. J., Crow, M. J., and Milsom, J. S., 2005. Sumatra: Geology, resources and tectonic evolution.

Bilek, S. L., Engdahl, E. R., DeShon, H. R., and El Hariri, M., 2011. The 25 October 2010 Sumatra tsunami earthquake: Slip in a slow patch. Geophysical Research Letters ,38.

Bock, Y., Prawirodirdjo, L., Genrich, J.F., Stevens, C.W., McCaffrey, R., Subarya, C., Puntodewo, S.S.O., and Calais, E., 2003. Crustal motion in Indonesia from Global Positioning System measurements. Journal of Geophysical Research, Solid Earth, 108.

Bora, D. K., Borah, K., Mahanta, R., and Borgohain, J. M., 2018. Seismic b-values and its correlation with seismic moment and Bouguer gravity anomaly over Indo-Burma ranges of northeast India: Tectonic implications. Tectonophysics, 728-729, 130-141.

Chlieh, M., Avouac, J. P., Sieh, K., Natawidjaja, D.H., and Galetzka, J., 2008. Heterogeneous coupling of the Sumatran megathrust constrained by geodetic and paleogeodetic measurements. Journal of Geophysical Research: Solid Earth, 113.

Collings, R., Lange, D., Rietbrock, A., Tilmann, F., Natawidjaja, D., Suwargadi, B., Miller, M., and Saul, J., 2012. Structure and seismogenic properties of the Mentawai segment of the Sumatra subduction zone revealed by local earthquake traveltime tomography. Journal of Geophysical Research, Solid Earth, 117.

Darman, H., and Sidi, F.H., 2000. An outline of the geology of Indonesia. Ikatan Ahli Geologi Indonesia, Jakarta.

Gahalaut, V.K., Nagarajan, B., Catherine, J.K., and Kumar, S., 2006. Constraints on 2004 Sumatra-Andaman earthquake rupture from GPS measurements in Andaman-Nicobar Islands. Earth and Planetary Science Letters, 242, 365-374.

Gui, Z., Bai, Y., Wang, Z., Li, T., 2019. Seismic b-value anomalies in the Sumatran region: Seismotectonic implications. Journal of Asian Earth Sciences 173, 29-41.

Gutenberg, B., and Richter, C.F., 1944. Frequency of earthquakes in California. Bulletin of the Seismological Society of America 34, 185-188.

Guttorp, P., 1987. On least-squares estimation of b values. Bulletin of the Seismological Society of America 77, 2115-2124.

Hatzidimitriou, P.M., Papadimitriou, E.E., Mountrakis, D.M., and Papazachos, B.C., 1985. The seismic parameter $\mathrm{b}$ of the frequency-magnitude relation and its association with the geological zones in the area of Greece. Tectonophysics, 120, 141-151.

Imoto, M., 1991. Changes in the magnitude-frequency b-value prior to large $(M \geqslant 6.0)$ earthquakes in Japan. Tectonophysics, 193, 311-325.

Konca, A.O., Avouac, J.-P., Sladen, A., Meltzner, A.J., Sieh, K., Fang, P., Li, Z., Galetzka, J., Genrich, J., Chlieh, M., Natawidjaja, D.H., Bock, Y., Fielding, E.J., Ji, C., and Helmberger, D. V, 2008. Partial rupture of a locked patch of the Sumatra megathrust during the 2007 earthquake sequence. Nature, 456, 631-635.

Mccaffrey, R., 2009. The Tectonic Framework of the Sumatran Subduction Zone, Earth Planet Science, 3737, 345-366.

McCloskey, J., Lange, D., Tilmann, F., Nalbant, S. S., Bell, A.F., Natawidjaja, D.H., Rietbrock, A., 2010. The September 2009 Padang earthquake. Nature Geoscience, 3, 70-71.

Meltzner, A. J., Sieh, K., Chiang, H.-W., Shen, C.-C., Suwargadi, B.W., Natawidjaja, D.H., Philibosian, B., and Briggs, R.W., 2012. Persistent termini of 2004- and 2005-like ruptures of the Sunda megathrust. Journal of Geophysical Research, Solid Earth, 117.

Moeremans, R.E., and Singh, S.C., 2015. Fore-arc basin deformation in the Andaman-Nicobar segment of the Sumatra-Andaman subduction zone: Insight from high-resolution seismic reflection data. Tectonics, 34, 1736-1750.

Mogi, K., 1963. Magnitude-frequency relation for elastic shocks accompanying fractures of various materials and some related problems in earthquakes (2nd Paper). Bulletin of the Earthquake Research Institute, University of Tokyo, 40, 831-853.

Molchan, G. M., and Dmitrieva, O.E., 1990. Dynamics of the magnitude-frequency relation for foreshocks. Physics of the Earth and Planetary Interiors, 61, 99-112. 
Natawidjaja, D.H., Sieh, K., Galetzka, J., Suwargadi, B.W., Cheng, H., Edwards, R.L., and Chlieh, M., 2007. Interseismic deformation above the Sunda Megathrust recorded in coral microatolls of the Mentawai islands, West Sumatra. Journal of Geophysical Research: Solid Earth, 112.

Nuannin, P., and Kulhánek, O., 2012. A Study of b-value Precursors Applied to the Andaman-Sumatra Region. Journal of Earth Science and Engineering, 2, 166-188.

Nuannin, P., Kulhanek, O., and Persson, L., 2005. Spatial and temporal b value anomalies preceding the devastating off coast of NW Sumatra earthquake of December 26, 2004. Geophysical Research Letters, 32.

Pailoplee, S., Surakiatchai, P., and Charusiri, P., 2013. FB-Value anomalies along the northern segment of the sumatra-andaman subduction zone: Journal of Earthquake and Tsunami, 07.

Pollitz, F.F., Banerjee, P., Bürgmann, R., Hashimoto, M., and Choosakul, N., 2006. Stress changes along the Sunda trench following the 26 December 2004 Sumatra-Andaman and 28 March 2005 Nias earthquakes. Geophysical Research Letters, 33.

Pollitz, F.F., Stein, R.S., Sevilgen, V., and Bürgmann, R., 2012. The 11 April 2012 east Indian Ocean earthquake triggered large aftershocks worldwide. Nature, 490, 250-253.

Prawirodirdjo, L., and Bock, Y., 2004. Instantaneous global plate motion model from 12 years of continuous GPS observations. Journal of Geophysical Research: Solid Earth, 109.

Sahu, O.P., and Saikia, M.M., 1994. The b value before the 6th August, 1988 India-Myanmar Border Region Earthquake: a case study. Tectonophysics, 234, 349-354.

Scholz, C.H., 1968. The frequency-magnitude relation of microfracturing in rock and its relation to earthquakes. Bulletin of the Seismological Society of America, 58, 399-415.

Shakir, M.M., and Barno, J.M., 2020. Rock joints analysis to determine the main stress, Iraqi Geological Journal, 53, 56-67.

Sieh, K., and Natawidjaja, D., 2000. Neotectonics of the Sumatran fault, Indonesia. Journal of Geophysical Research: Solid Earth, 105, 28295-28326.

Tsang, L.L.H., Meltzner, A.J., Philibosian, B., Hill, E.M., Freymueller, J.T., and Sieh, K., 2015. A 15 year slowslip event on the Sunda megathrust offshore Sumatra. Geophysical Research Letters, 42, 6630-6638.

Urbancic, T.I., Trifu, C.-I., Long, J.M., and Young, R.P., 1992. Space-time correlations of b values with stress release. Pure and Applied Geophysics, 139, 449-462.

Westerhaus, M., Wyss, M., Yilmaz, R., and Zschau, J., 2002. Correlating variations of b values and crustal deformations during the 1990s may have pinpointed the rupture initiation of the $\mathrm{Mw}=7.4$ Izmit earthquake of 1999 August 17. Geophysical Journal International, 148, 139-152.

Wiemer, S., and McNutt, S.R., 1997. Variations in the frequency-magnitude distribution with depth in two volcanic areas: Mount St. Helens, Washington, and Mt. Spurr, Alaska. Geophysical Research Letters, 24, 189-192.

Wyss, M., 1973. Towards a physical understanding of the earthquake frequency distribution. Geophysical Journal International, 31, 341-359.

Xie, W., Hattori, K., and Han, P., 2019. Temporal variation and statistical assessment of the b value off the Pacific Coast of Tokachi, Hokkaido, Japan. Entropy, 21, 249. 